\title{
Challenges and opportunities for the regeneration of multinational worker cooperatives: Lessons from the Mondragon Corporation-a case study of the Fagor Ederlan Group
}

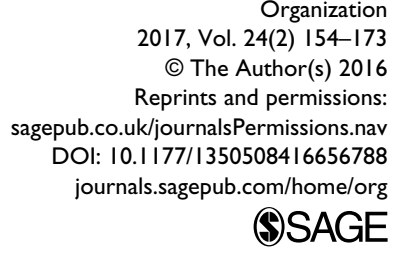

\author{
Ignacio Bretos and Anjel Errasti \\ University of the Basque Country, Spain
}

\begin{abstract}
Organisations with alternative structures have been forced to grow internationally in order to remain competitive in the current global context. Some of the industrial cooperatives that belong to the Mondragon Corporation have since the 1990s followed internationalisation strategies that have increased their competitiveness, the number of their employees and their ability to create wealth. However, these moves have also called into question the founding nature of these enterprises. Recently, the Corporation itself has adopted a discourse based on strengthening workers' participation in capitalist subsidiaries, but to date, the initiatives taken by its multinational cooperatives have been few and the results not particularly impressive. This article investigates this disconnect, delving into the problems of replicating the cooperative model in these subsidiaries and seeking solutions. It focuses on the case of Fagor Ederlan (Mondragon Corporation), examining the efforts to transform capitalist subsidiaries, especially the 'cooperativisation' of the Fagor subsidiary in Tafalla (Spain), which is the biggest regeneration project in Mondragon's Industrial Division. This work also contributes to the broader field of organisational theory by analysing the tensions and opportunities for regeneration in worker-owned organisations under the current globalised context.
\end{abstract}

\section{Keywords}

Cooperative regeneration, degeneration, Fagor Ederlan Group, internationalisation, Mondragon, worker cooperatives

\section{Corresponding author:}

Ignacio Bretos, GEZKI-Institute of Cooperative Law and Social Economy, University of the Basque Country, Plaza Elhuyar 2, Donostia-San Sebastián 20018, Spain.

Email: ignaciobretos@gmail.com 


\section{Introduction}

Worker-owned cooperatives as alternative organisations in an adverse, capitalist setting have always found it challenging to survive without forgoing their essential nature (Parker et al., 2014), raising questions about whether cooperatives reproduce the capitalist system or function as its gravediggers (Paranque and Willmott, 2014). Globalisation has brought about a new scenario for alternative organisations, and recent literature has particularly focused on the internal contradictions and paradoxical practices that these organisations exhibit (e.g. Cathcart, 2013; Heras, 2014; Stohl and Cheney, 2001), generally neglecting the possibilities for their organisational regeneration.

One of the most powerful trends of current globalisation is that international expansion has become a prerequisite for competitiveness - something that worker-owned firms are by no means immune to (Flecha and Ngai, 2014). As a result, many such firms have turned into multinational companies (MNCs) with capitalist subsidiaries abroad. This has increased degenerative tensions but also created opportunities for regeneration as these organisations seek to grow in a way consistent with their founding values (McMurtry and Reed, 2009). As Cheney et al. (2014) state, currently a key line of research is to investigate how multinational cooperatives can transfer their workercentric policies and practices to their capitalist subsidiaries.

Mondragon's Industrial Division, with 31,736 workers (11,312 of them abroad), a total turnover of $€ 4754$ million ( $70.6 \%$ corresponds to foreign sales) and 125 foreign subsidiaries (property of 28 multinational cooperatives) (Mondragon, 2015), forms a fruitful field to study these issues. The internationalisation strategy followed since the 1990s by several industrial cooperatives has encouraged their competitiveness, increased employment and wealth creation (Luzarraga and Irizar, 2012) and helped them to weather economic crises (Elortza et al., 2012). However, it has also exhibited stark degenerative dynamics, as evidenced by the setting up of capitalist subsidiaries (Errasti et al., 2003) and the decrease in the ratio of cooperative employment from $86 \%$ in 1991 to $29.5 \%$ in 2007 (Storey et al., 2014). In recent years, Mondragon has promoted a discourse of regeneration based on encouraging worker participation at its capitalist subsidiaries (Azkarraga et al., 2012), although to date, few such initiatives have been implemented, and results have been limited. Researches analysing these regeneration projects (e.g. Flecha and Ngai, 2014; Storey et al., 2014) have perhaps indulged in excessive romanticism, so possibilities for regeneration should be critically assessed.

This article contributes to the literature in two directions. First, it sets out to investigate the tensions and opportunities entailed in setting up regeneration schemes at multinational cooperatives, focusing on the problems parent companies face in reproducing the cooperative model in their capitalist subsidiaries and on potential solutions for those problems. Second, by analysing the degenerative tensions and paradoxical practices in alternative organisations, it aims to contribute to organisational theory by moving forward in the debate about the possibilities for regeneration under the current globalised context. To this end, we conduct a case study of Fagor Ederlan, one of the largest cooperatives in the Mondragon Group and the most active in implementing the cooperative model in its capitalist subsidiaries. It particularly focuses on the biggest regeneration initiative to date carried out by a Mondragon industrial cooperative: the conversion of the domestic subsidiary Fagor Ederlan Tafalla, with over 900 employees, into a mixed cooperative. Our findings suggest that internationalisation poses extraordinary challenges to cooperatives in managing the tensions between the economic and social dimensions. Moreover, this research shows that regeneration is feasible at multinational cooperatives either through the transformation of capitalist subsidiaries into cooperatives or via the promotion of worker participation in such subsidiaries. However, it also evidences the existence of external hurdles and, even more importantly, the internal reluctance on 
the part of parent-cooperative members and managers to foster the implementation of such regeneration schemes.

The article is structured as follows: 'Theoretical approach: dynamics of degeneration and regeneration in the development of cooperatives in the context of globalisation' section constructs a theoretical framework through a review of the literature on the degeneration and regeneration of cooperatives in a globalised capitalist setting. 'The case study: Fagor Ederlan Group — dynamics of regeneration in one of the largest Mondragon cooperatives' section introduces the case study of Fagor Ederlan and 'Data and methods' section details the data and methods used. The following sections present the main results of the research. The final section is devoted to discussion and conclusions.

\section{Theoretical approach: dynamics of degeneration and regeneration in the development of cooperatives in the context of globalisation}

The viability of alternative organisations in a capitalist setting has been a topic of debate throughout the 20th century. There have been two main lines of research challenging the classic 'degeneration thesis', according to which worker-owned organisations are inevitably destined to fail or degenerate into capitalist forms (Ben-ner, 1984; Meister, 1974, 1984; Miyazaki, 1984; Webb and Webb, 1920): one suggesting the possibility of these organisations maintaining their foundational nature in the long term (Bernstein, 1976; Rothschild-Whitt, 1976; Rothschild-Whitt and Whitt, 1986) and the other claiming that degeneration may be a temporary stage followed by regeneration processes capable of restoring the cooperative nature of these organisations (Batstone, 1983; Cornforth, 1995; Cornforth et al., 1988; Rosner, 1984; Stryjan, 1994). In the past decades, globalisation has forced the internationalisation of many worker-owned organisations that now operate with subsidiaries abroad (Côté, 2001; Flecha and Ngai, 2014), thus accentuating new tensions and opportunities for these organisations to combine economic success and social commitment (McMurtry and Reed, 2009). Indeed, as some authors note, one of the main challenges for cooperatives today is to integrate and replicate the cooperative model during international expansion (Cheney et al., 2014; Flecha and Ngai, 2014).

Recent literature has mainly focused on the contradictions and paradoxical practices that arise from the difficulty of putting principles and values (such as democratic participation or equity) into practice and aligning them with the economic pressure to survive (Ashforth and Reingen, 2014; Cathcart, 2013; Heras, 2014; Stohl and Cheney, 2001; Varman and Chakrabarti, 2004). Some research has also refocused attention on the 'degeneration thesis' by pointing out key dynamics under the new competitive setting such as the appointment of managers more committed to economic efficiency (Spear, 2004) or the necessity of hiring salaried workers and acquiring capitalist firms to remain competitive (Errasti, 2015). On the other hand, new literature challenging the 'degeneration thesis' has focused on the comparative efficiency of worker-owned firms (Burdin, 2014), or on the possibility of these firms preserving their original nature (Sauser, 2009). Less attention, however, has been paid to the new tensions and opportunities for regeneration in such organisations.

The literature on the Mondragon Group exemplifies the evolution of alternative organisations. Born more than half a century ago as a communitarian experiment inspired by the Catholic social doctrine, Mondragon was initially characterised by a particular religious and hierarchical approach to worker participation grounded in three principles: ownership, direction or authority and the distribution of profit (Azkarraga et al., 2012: 78). As Heras (2014) argues, in the first decades, ideological criticism was palpable in the social environment of Mondragon and was expressed in 
several studies. However, the adaptation of Mondragon to globalisation, particularly reflected in the international expansion of several of its industrial cooperatives since the 1990s, has given rise to a heated debate.

Some researchers argue that competitive pressures have instilled in Mondragon a rhetoric centred on efficiency (Taylor, 1994), where self-management and democratic participation has been cast into a more conventional techno-structure and managerial mould (Cheney, 1999, 2005; Heras, 2013, 2014). As these authors suggest, worker participation is now more managerially oriented, focused on the workplace and assessed in terms of employee motivation and commitment to organisational objectives; elements that find shelter under the label of employee involvement (Wilkinson et al., 2010). Furthermore, international expansion has been also seen as a driver for degeneration (Bakaikoa et al., 2004; Errasti et al., 2003), given the setting up of capitalist subsidiaries around the core cooperatives and the creation of non-cooperative jobs with social and working conditions very different from those enjoyed by cooperative members (Clamp, 2000). On the other hand, as Heras (2014) claims, the managerial discourse, together with the impressive economic benefits of internationalisation and the organisation's responsiveness to economic crises, have given rise to an uncritical literature that extols Mondragon as the poster child of combining economic success with democratic methods (e.g. Arando et al., 2010; Forcadell, 2005). Regarding the model of internationalisation, it is highlighted as an example of harmonisation between globalisation and cooperatives, since it has managed to create jobs and wealth abroad while generating cooperative jobs at Basque plants (Luzarraga et al., 2007; Luzarraga and Irizar, 2012).

In the last years a renewed, more realistic debate on participation, motivated by internal selfreflection and scholarly scrutiny (Azkarraga et al., 2012), has led Mondragon to recognise these contradictions. The 8th Mondragon Cooperative Congress, which took place in 2003, approved a strategy of 'social expansion' (Irizar, 2005) based on the dissemination of cooperative values at subsidiaries by means of mechanisms for participation similar to those in place at the core cooperatives (Flecha and Ngai, 2014). Some cooperatives have adopted a discourse of regeneration based on fostering the participation of the workers employed by their capitalist subsidiaries (Altuna, 2008; Azkarraga et al., 2012). The few scholars who have examined specific regeneration schemes (Bakaikoa et al., 2013; Flecha and Ngai, 2014; Luzarraga, 2008; Luzarraga and Irizar, 2012; Storey et al., 2014) assert that large Mondragon cooperatives are regenerating. However, a conclusion that can be drawn from these studies is that such regeneration schemes are relatively rare and that the ones that have been implemented have not managed to significantly encourage workers to participate in the management, ownership and profits of subsidiaries, particularly abroad. Therefore, it seems necessary to shed light upon the workings of regeneration schemes in more detail. Why exactly have the results not been more impressive? What are the challenges involved? Is the whole focus on regeneration merely a rhetorical one, detached from any intention to actually implement such practices? These are the questions our case study of Fagor Ederlan explores.

\section{The case study: Fagor Ederlan Group-dynamics of regeneration in one of the largest Mondragon cooperatives}

Fagor Ederlan, founded in 1963, is one of the flagships of the Mondragon Group and one of its most active cooperatives in terms of international expansion (Koop, 2015). It is currently one of the world's leading automotive suppliers, and is engaged in the design, development and manufacture of metal components for chassis and powertrains. The internationalisation strategy adopted by Fagor Ederlan since the 1990s is a perfect example of the general strategy described for Mondragon. To remain competitive, Fagor Ederlan has adopted a model of growth based on 
creating or acquiring capitalist subsidiaries, first in the domestic market and subsequently abroad, that has encouraged the creation of non-cooperative jobs abroad and cooperative jobs in the Basque plants.

Thus, 2007 saw the consolidation of the Fagor Ederlan Group, led by Fagor Ederlan S. Coop. and currently made up of its eight Basque plants plus its partly owned subsidiaries Fagor Ederlan Tafalla S. Coop., Fagor Ederlan Borja S.A. and Victorio Luzuriaga Usurbil in Spain, and Fagor Ederlan Brasileira (Brazil), Fagor Ederlan Slovensko (Slovakia) and Fagor Ederlan Auto-Parts Kunshan (China) abroad. ${ }^{1}$ It also has a technology centre, Edertek S. Coop., in Mondragon, two production partnership agreements with the United States and South Korea and eight sales offices in Europe, Asia and North America. In 2014 the Group's workforce numbered 3559, its sales totalled $€ 651$ million (with around $70 \%$ being foreign sales), and it made investments to the tune of $€ 43$ million (Fagor Ederlan, 2015).

Besides investing heavily in internationalisation, Fagor Ederlan has in recent years become one of the leading cooperatives at Mondragon in the adoption of regeneration schemes. At Mondragon in general, two main lines of regenerative action can be distinguished (Ugalde et al., 2009). The first, more direct line involves cooperativising subsidiaries. There are two main ways of doing this. One involves creating a mixed cooperative, ${ }^{2}$ that is, the capitalist subsidiary is converted into a cooperative partly owned by the workers of the subsidiary, with the rest usually being owned by the parent company of the group or even by third parties such as Mondragon Inversiones. The other entails a structure known as secondment of members, ${ }^{3}$ meaning that a number of workers at the subsidiary become members of the parent cooperative, even though the subsidiary continues to be capitalistic in form. These structures are not new: in 2004 around 15\% of all the group's industrial jobs consisted of cooperativisations of this type (TuLankide, 2004), but hitherto the system has only been used at the domestic level. The second line of action, mainly designed for foreign subsidiaries, consists of implementing the Mondragon management model at capitalist subsidiaries through a system known as Corporate Development (Mondragon, 2013), which introduces a number of indicators regarding the management and participation of workers in the subsidiaries in an attempt to bring them closer to the parent-cooperative structure. Nevertheless, this system is neither a detailed action plan nor a binding regulation; it only provides some general guidelines.

\section{Data and methods}

The method used to investigate Fagor Ederlan is that of 'contemporary case studies' (Yin, 2003). The aim is to obtain an in-depth knowledge of the complex process of turning a public limited liability company into a cooperative, and the method also serves to analyse the dilemmas and possibilities in terms of encouraging the participation of workers at subsidiaries (Myers, 2009). Moreover, as pointed out by Cornforth (1995), analysing degeneration and regeneration dynamics at cooperatives is a complex matter. Purely theoretical approaches or purely quantitative techniques based on highly limited periods of time are unlikely to shed much light on the matter. The method used here overcomes this problem, as it brings together various techniques in a continuous, across-the-board analysis of degeneration/regeneration processes (Chetty, 1996). Bearing in mind the limitations involved in drawing any general conclusions for multinational cooperatives based on the analysis of a single case (Eisenhardt, 1989), it is worth highlighting the great potential of the methodology and the case study selected in reliably helping us pursue our objectives.

Our case study of Fagor Ederlan utilised multiple techniques and drew on a variety of sources. We carried out 12 in-depth face-to-face interviews ${ }^{4}$ over the course of a year, and consulted internal documents on the cooperative dating from the late 1990s to 2015. The interviews covered staff from different areas of Fagor Ederlan: the Chair of the Fagor Ederlan Group; the Tafalla 
Cooperativisation Project Coordinator, who was formerly the Head of Human Resources at Fagor Ederlan; a member of the Fagor Ederlan management staff who took charge at Tafalla of implementing the cooperativisation project, and who had previously taken part in a similar process at the subsidiary Fit Automoción S.A.; the current Chair of Fagor Ederlan Tafalla, who had previously chaired the Works Committee at the subsidiary; the Head of Personnel at the subsidiary in Tafalla; a trade union delegate from Comisiones Obreras Navarra who was involved in the cooperativisation process at Tafalla; two employees of Fagor Ederlan Tafalla who became members in the course of the cooperativisation process; two employees who continued as salaried workers following the process; and two cooperative members of the parent company Fagor Ederlan.

The interviews with top management at Fagor Ederlan and at the subsidiary in Tafalla (1-5) were conducted at the headquarters of the companies in Eskoriatza (Guipúzcoa) and Tafalla (Navarre), where we also visited the plants. These interviews focused on examining the contradictions found in the capitalist subsidiaries, the regeneration schemes implemented (particularly at Fagor Ederlan Tafalla) and on the possibilities for regeneration at foreign subsidiaries. By contrast, the interviews with corporate members, salaried workers and trade union delegates (6-12) were conducted outside the workplace in order to assure absolute confidentiality and avoid 'organisational silence' (Morrison and Milliken, 2000), so that critical, truthful information could be obtained. These interviews focused on how the interviewees saw their participation in the management, ownership and profits of the cooperatives and on how they viewed the possibilities for implementing processes to encourage the participation of workers at foreign subsidiaries.

We also consulted a range of internal documentation provided by the company (sustainability reports, strategy plans, company articles, internal regulations, etc.). In particular, we were provided with an in-house working document that recorded 127 individual interviews with staff at the subsidiary in an investigation of the results of the cooperativisation process in terms of the participation and integration of workers in the new cooperative model. Finally, we also contacted core organisations at Mondragon involved in regeneration processes, such as the Lankidetzaren Ikertegia (LANKI) Institute and the (Mondragon Innovation and Knowledge (MIK) research centre. Through these contacts we were able to access a study by the MIK of the experience of trade union representatives at Fagor Ederlan Tafalla regarding worker participation following the cooperativisation process. Furthermore, we consulted external publications concerned with Fagor Ederlan and the Mondragon Group, press releases and material from their own websites.

\section{The 'cooperativisation' of Fagor Ederlan Tafalla}

\section{Key elements of the process}

The Fagor Group acquired Victorio Luzuriaga Tafalla (currently called Fagor Ederlan Tafalla) in 1990, and in 1995, Fagor Ederlan and the Mondragon Group acquired stakes in the company due to the strategic situation of Tafalla in the region of Navarre, where there is an important network of activities around the automotive sector. In 2000, an ideological debate was initiated at the Fagor Ederlan board concerning the need to strengthen the participation of workers in the associated companies, which bore fruit when the cooperativisation of partly owned subsidiaries was defined as one of the goals of the 2005-2008 Strategy Plans. In order to develop future cooperativisation initiatives, Fagor Ederlan acquired greater control over the subsidiary of Tafalla: in 2005, its capital stock was divided between Fagor Ederlan (2/3) and Mondragon (1/3). Thus, in 2006, work began at Fagor Ederlan on the project to cooperativise the Tafalla plant. Other aspects also influenced this decision: the company was facing economic problems, and so a strong modernisation of the plant was necessary in order to avoid dismissals. As a member of the top management noted, 
At that time the situation at the subsidiary in Tafalla was complex, as the company needed a restructuring that entailed considerable financial investment to renovate equipment, production processes and organisational models [...]. Fagor Ederlan was unwilling to plough that much funding into a capitalist subsidiary. (I3, top management staff member at Fagor Ederlan)

The cooperativisation project in Fagor Ederlan Tafalla, like others in Mondragon, was not driven by the company's workers (Ugalde et al., 2009), but by the techno-structure of Fagor Ederlan. The 'Cooperativisation Project Team', made up of members of Fagor Ederlan's top management staff, determined the most suitable model of cooperativisation for this particular subsidiary. Rather than turning the company directly into a cooperative or merely promoting the participation of workers without a significant transformation, a mixed cooperative system was decided on, with participation by Mondragon, Fagor Ederlan and future members from Tafalla. This was done for two reasons. First, the financial outlay required to acquire $100 \%$ ownership of the subsidiary would have been beyond the resources of potential members. ${ }^{5}$ Second, Mondragon and Fagor Ederlan wished to maintain some control over the company due to the uncertainties that might arise from the possible lack of cooperative culture and experience among members at the outset (Fagor Ederlan, 2006).

Once the outline of the cooperativisation project had been defined, the next step was to study the legal, social and economic viability for its implementation. The legislation on cooperatives in force in Navarre did not envisage the possibility of a project such as this one, but thanks to the lobbying of Mondragon, a new Cooperatives Act (Ley Foral 14/2006 de Cooperativas) was passed in Navarre in November 2006. The new act permitted projects such as the one designed for the subsidiary in Tafalla to go ahead. As regards economic issues, a financial viability study of the plant was carried out by the Finance Division of Fagor Ederlan, covering the investment requirements in Fagor Ederlan Tafalla and its economic viability in the medium to long-term. The social viability study entailed a prospecting survey to gauge the level of receptiveness of workers regarding the project; this involved about 250 interviews carried out over 5 months by the members of the Cooperativisation Project Team.

Subsequently, following coordination and consensus work with the agents involved (top management and the works committee at the subsidiary, the governing board of the parent company, the Spanish Department of Employment (Instituto Nacional de Empleo (INEM)), the Labour Inspectorate, the Regional Government of Navarre and the Caja Laboral savings bank), the project was submitted to the workers at the subsidiary, on the terms of a non-divisible business/membership proposal, that is, a project in which the investment of $€ 60$ million in the plant were inextricably linked to its conversion into a cooperative. Accordingly, the governing board of Fagor Ederlan set minimum requirements under which the project would go ahead: at least half of the 700 workers on indefinite contracts at that time (the $150+$ casual workers were not taken into account) would have to become members. Given initial trade union resistance to the project, the Cooperativisation Team tried to diminish union power. The trade union delegate claimed that

Cooperativisation was a process intended to force employees to buy their own jobs for $€ 13,000$ each [...]. The first step of the Fagor Ederlan's management board was to annul the power of trade unions [...]. It was blackmail from our point of view. No cooperativisation, no investment and everybody out on the street! Tafalla has been a region with a long trade union tradition, but this obliged us to accept the deal and step aside. (I6, delegate of the Comisiones Obreras Navarra trade union)

After overcoming the opposition of trade unions and conducting 2 months of small-group meetings with workers, where the project and the cooperative model were explained and in which nonbinding surveys were held in order to assess the level of receptiveness, the project was submitted 


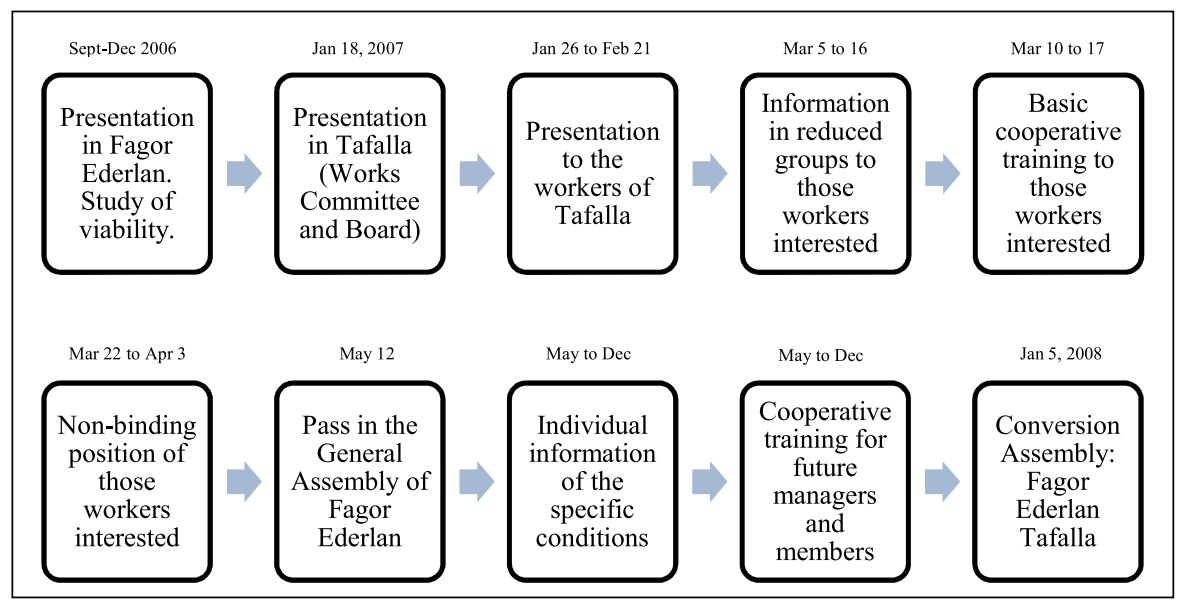

Figure I. Stages of the cooperativisation project in Fagor Ederlan Tafalla.

Source: Fagor Ederlan (2006).

to the General Assembly of Fagor Ederlan and unanimously approved. Over the following 8 months, the future members and managers of Fagor Ederlan Tafalla were informed in face-to-face interviews of their future social and labour conditions, and Mondragon provided them training in its cooperative culture and model of management.

When, on 5 January 2008, the Conversion Assembly took place, the limited liability trading company Victorio Luzuriaga Tafalla S.A. became the mixed cooperative Fagor Ederlan Tafalla S. Coop. (see Figure 1 for a synopsis). The company's capital stock was initially held as follows: cooperative members 12\%, Fagor Ederlan S. Coop 60\% and Mondragon 28\%. The minimum requirement was met by a narrow margin. Nonetheless, around $70 \%$ of the workers who decided not to become members of the cooperative were nearing retirement age, and claimed reasons related to a possible deterioration in their pensions (Fagor Ederlan, 2010). As a result, only 35 of the salaried workers who did not become cooperative members in 2008 currently remain at the subsidiary.

The interviewees agreed that the success of the process was based on three areas: information, communication and training. The Coordinator summarised it in this way:

The success of the process certainly lay in communication and transparency. A great many briefings, interviews and non-binding surveys were held [...]. Everyone at the subsidiary was informed clearly of just what cooperativisation meant, and what their new circumstances would be if they became cooperative members [...]. Another key point was the intensive process of training and education in cooperative principles and values and in the new way of working under the cooperative model. (I2, Cooperativisation Project Coordinator at Tafalla)

However, almost $80 \%$ of those who became members stated that their reason for doing so was the increased job security offered by the new cooperative model. Furthermore, 1 year after the cooperativisation, only $7 \%$ of the members claimed to know what exactly the cooperative principles of Mondragon comprise (Fagor Ederlan, 2010). This indicates that the principle of job security is the most solid tie binding members to the organisation (Heras, 2014), and may signal a lack of commitment to the formal cooperative principles of Mondragon that could be detrimental to the stability of the cooperative in the future. 
Fagor Ederlan Tafalla S. Coop. currently produces engine blocks and cylinder heads. In 2014, its workforce numbered 688 (485 cooperative members, 52 salaried workers on indefinite contracts and 151 salaried workers on casual work contracts). Sales abroad accounted for $65 \%$ of the company's total sales, and investment for the period 2010-2014 totalled $€ 60$ million. From 2008 to 2014, the number of cooperative members increased from 355 to 485, and the company's capital in the hands of its worker members rose to $20 \%$ (Fagor Ederlan, 2015). Moreover, the transformation of Fagor Ederlan Tafalla, along with other regeneration projects implemented, increased the proportion of cooperative worker members in the group as a whole from $36 \%$ in 2007 to $49 \%$ in 2008 (Fagor Ederlan, 2009), and to 65\% in 2015 (Koop, 2015).

\section{Workers' participation in the new cooperative}

As the concept of workplace democracy has been picked up by the mainstream corporate philosophy and managerial discourse (Stohl and Cheney, 2001) and associated with a great variety of forms and processes (Cheney et al., 2012), it has become so generalised and amorphous (Budd, 2004) as to significantly decrease in usefulness, especially when trying to analyse organisations with complex participatory traditions and internal tensions such as Mondragon (Heras, 2014). Following Cheney et al. (2012), we attempt to assess concepts such as 'democracy' and 'participation' in terms of how they are constituted or demonstrated in practice. Therefore, we next focus on the features and practices that differentiate worker cooperatives from 'regular' capitalist enterprises: participation in ownership, profits and management (Cheney et al., 2014).

First, under the company articles, the General Assembly is not run on the usual 'one person one vote' basis for worker members from Tafalla; instead, a majority of votes are in the hands of Fagor Ederlan and Mondragon. However, the worker members at the subsidiary are over-represented in the governance organs. In the words of the Project Coordinator:

Fagor Ederlan and Mondragon have never used their majority decision-making power: they take part in general assemblies with one vote each, equivalent to the individual votes of the worker members from Fagor Ederlan Tafalla. Therefore, in important issues such as wage cuts, increases in capital, investment, etc. an a priori consensus is always sought between Fagor Ederlan, Mondragon and the subsidiary, and the final decision is exclusively up to the worker members. (I2, Cooperativisation Project Coordinator at Tafalla)

A 12-person governing board was set up in a way that ensured that the worker members from the subsidiary had a greater representation than the $12 \%$ that they would have been allocated on the basis of their proportion of ownership. Five of the 12 governing board members were worker members from Tafalla, five from Fagor Ederlan and two from Mondragon. This meant that in important decisions, which under the company articles require a two-thirds majority, the vote in favour of the representatives of Tafalla is needed. Moreover, a special organ, the 'Delegate Committee', was formed by representatives of the worker members on the Governing Board. This organ is integrated into the Governing Board, and so it does not maintain a close relationship with other governance organs. Its decision-making domain only covers operational issues such as the approval of requests for a leave of absence, the establishment of work schedule or the adoption of internal regulations. The Chair of Fagor Ederlan Tafalla had this to say:

To ensure that the worker members at the subsidiary had a higher level of self-management, the 'Delegate Committee' was set up. This was a body made up entirely of representatives of the worker members on the Governing Board, plus the Chair. It had the authority to decide independently on operational issues that arose in the day-to-day running of the subsidiary. (I4, Chair of Fagor Ederlan Tafalla) 
After its cooperativisation, Fagor Ederlan Tafalla replicated the management model of its parent company, implementing the Fagor Ederlan Participation System. This system defines itself as 'contributing by taking an active part in the definition, execution, assessment, coordination and improvement of all processes and areas of activity at the company'. It covers improvement management (contributing to the attainment of goals), process management (helping to meet the needs of the internal and external customers of the processes involved) and activity management (contributing to the improvement, effectiveness and safety of the tasks carried out). The main worker participation mechanisms include teamwork, training and education for workers (both education in cooperative values and training in the more technical aspects of their area of work), in-house communication, a system of suggestions from workers and the flagging up by workers of potential risks in the workplace (Fagor Ederlan, 2009). These mechanisms are developed by implementing the 'mini-companies' system. A member of the top management explains it in these terms:

Mini-companies are forms of organisation designed to give more autonomy to workers in production areas. It is they who make decisions and solve problems on the ground, right where they arise [...]. The idea is to set up a horizontal system of participation so that problems and solutions are not handed down from the management. These units are provided with support and backing from all areas of the company (quality, risk prevention, etc). (I3, top management staff member at Fagor Ederlan)

In short, the incorporation of this management model following the cooperativisation of the subsidiary has increased worker participation, encouraging self-management and a horizontal outlook in regard to labour relations and the company's organisational structure. In the words of a cooperative member of Fagor Ederlan Tafalla:

The social and labour-related circumstances of cooperative members and salaried workers have changed drastically under the new cooperative model. Whereas before we worked according to a hierarchical system there is now a high level of commitment and participation of workers in the company. (I7, cooperative worker member)

However, the cooperativisation process also harmed the relationships between cooperative members and salaried workers on one hand, and between the governing board and the trade unions on the other. The Social Council made efforts to normalise relations. For example, salaried workers were invited to an extraordinary General Assembly, but they were not placated and instead disrupted the event by protesting, so the Social Council gave up interceding. In late 2008, the situation exploded: members reduced their salary by $6 \%$ to combat the effects of the economic crisis. Initially salaried employees did not accept an equivalent reduction and went on strike. The Fagor Ederlan board response was to threaten the dismissal of 61 workers, causing the salaried employees to acquiesce in the salary cut. The trade union delegate had this to say:

The threat of dismissal of 61 salaried employees on the part of the management for refusing to accept wage cuts opened up a big gap between cooperative members and salaried workers that can still be seen today. (I6, delegate of the Comisiones Obreras Navarra trade union)

The cooperativisation of the subsidiary also led to salaried workers having more say in the dayto-day management of issues affecting their jobs, but there has been no progress in encouraging them to participate in the ownership, governing bodies and profits of the company. This is what a salaried worker at Tafalla had to say:

Those of us on a salary have been required to accept wage cuts comparable to those of the cooperative members, but there is a widespread feeling that we cannot voice our opinions or take part in important 
decisions affecting the company [...]. It is true that there has been a change in the way in which work is structured, and that we all now have more autonomy and are continually involved in work teams. However we cannot attend assemblies and the works committee has lost a great deal of influence at the company. (I9, salaried worker at Tafalla)

The differential treatment of members and salaried workers-evident not so much in labour conditions (wages, hours ...) but rather in decision-making capacity and participation in the cooperative - is a common element in many cooperatives of Mondragon (Arando et al., 2010), and certainly undermines the cooperative nature of these organisations. The problems at Tafalla have been evident also in similar projects developed by other cooperatives of Mondragon: the cooperativisation of the enterprise tends to lead to a clear differentiation of the participatory praxis between members and salaried employees (Ugalde et al., 2009), as well as to reduction in the power of the works council, with the consequent deterioration of the representation of the latter in the cooperative (Arregi et al., 2012).

\section{Initiatives taken to cooperativise other capitalist subsidiaries}

Fagor Ederlan has also carried out regeneration initiatives at its Basque subsidiaries FIT Automoción Bergara S.A. and Victorio Luzuriaga Usurbil S.A., through the 'seconded members' system. In 2006, 78 of the 83 workers at FIT Automoción became cooperative members seconded from the parent company Fagor Ederlan. This subsidiary is $66 \%$ owned by Fagor Ederlan and Mondragon, with the remaining 34\% owned by a German public limited liability company (Mondragon, 2006). It maintained the same legal form but effectively became one more plant of the parent company. The company Victorio Luzuriaga Usurbil is currently undergoing the same process, which is expected to be completed by 2016 .

By contrast, there has been little progress in cooperativising the remaining subsidiaries. The managerial discourse of Mondragon (Cheney, 2005; Heras, 2013, 2014) is evident here. Previous research (Flecha and Ngai, 2014) has identified four barriers preventing the cooperativisation of subsidiaries which are, in fact, the main pillars supporting the managerial discourse justifying the non-conversion of subsidiaries: economic barriers (before workers can become cooperative members the subsidiary must be economically profitable), legal barriers (many countries lack relevant legislation on cooperatives, or do not have legislation similar to that of the Basque Country), cultural barriers (lack of cooperative culture and spirit among the workers at subsidiaries) and investment-related barriers (fear of members of the parent cooperatives of losing control over their capital investments if workers at foreign subsidiaries become members). These elements are omnipresent in Fagor Ederlan.

The first pillar of the managerial discourse is illustrated, for instance, in the following reference to the other domestic subsidiary, Fagor Ederlan Borja S.A:

The Borja plant makes a single product for a single customer. Its only partner is General Motors, so there is great uncertainty as to its future financial viability [...]. This prevents us from encouraging any kind of cooperativisation project there because of the great effort involved and the high risk regarding the possibility that the plant may have to close down in the future. (I1, Chair of the Fagor Ederlan Group)

'Legal barriers' are mentioned in the case of the Brazilian subsidiary, which stands out as the only case at Mondragon in which the possibility of converting a foreign subsidiary into a cooperative was considered. In this vein, as Muller-Camen et al. (2001) state, the strength of national institutional regulation is a determining factor for the manoeuvre of MNCs abroad. The same interviewee quoted above had this to say about it: 
In Brazil the possibility was considered of turning the plant into a cooperative, but the legal system there is very different from that in the Basque Country and it left very little room for manoeuvre [...]. Moreover, over there they see cooperatives very differently: the general public has perhaps a more negative view of them. (I1, Chair of the Fagor Ederlan Group)

\section{However, as a Lanki's internal report noted,}

the developing economy of Brazil, with a liberalizing regulation for the manoeuvre of businesses and a legislation on cooperatives that did not differ substantially from that of the Basque Country shaped an extraordinary opportunity for Mondragon to cooperativise the first foreign subsidiary [...] Their cooperative tradition also gave hope [...] The project was quickly closed, as opposed to other internationalisation projects where a capitalist subsidiary is established despite the legal differences with the domestic legislation. (Lanki, 2007: 3-4)

'Cultural barriers' are specially mentioned in the case of Fagor Ederlan Slovensko and particularly in Fagor Ederlan Auto-Parts Kunshan. Following Wood (2010), countries like China have a legacy of autocratic managerial-styles and centralised powers. In fact, as Errasti (2015) points out, workers at Mondragon subsidiaries at the Kunshan Park suggested that they would not be willing to work under the cooperative formula due to differences in social and labour-related culture. As a member of the top management explained,

The implementation of the cooperative formula at China is really complex due to their labour and social culture, which differs extraordinarily from our cooperative culture in the Basque Country. I think they are not used to making important decisions in groups and they would not understand that they have to put money in the cooperative. (I3, top management staff member at Fagor Ederlan)

Finally, 'investment-related barriers' were expressed in some way by all the cooperative members interviewed. One of them explained it clearly:

It is hard to place our trust and the control of the savings that we have invested in our cooperative in workers at foreign subsidiaries [...]. They [workers at foreign subsidiaries] cannot possibly devote as much time and effort to the company, because after all this company is ours [...]. Many of us have asked for bank loans to become worker members, and if the company doesn't make it then neither do we. (I8, worker member of Fagor Ederlan Tafalla)

Taking for granted the impossibility to transform subsidiaries - particularly those outside the Basque Country - into cooperatives, Mondragon has adopted a rhetoric that alludes to implementing schemes of worker participation in the ownership, management and profits at subsidiaries (Mondragon, 2013). As a result of the failure to cooperativise the Brazilian subsidiary, Fagor Ederlan established a number of comparative parameters to adapt various elements at capitalist subsidiaries that could bring them closer to a form of organisation similar to the parent cooperative. The Chair put it this way:

The goal is to extend this [cooperativist] spirit to associated companies, even when they are not formally structured as cooperatives. At the very least, their management models and their modus operandi must be consistent $[\ldots]$. We have issued a directive applicable to all the group's plants, listing 10 points for comparing subsidiaries with the parent cooperative. Those points include participation in capital, distribution of profits/losses, training programmes for personnel and shared management models. (I1, Chair of the Fagor Ederlan Group) 
These directives - which are not set in stone with a view to bringing about substantial changes, but should rather be seen as guidelines for comparing the operations of the subsidiary with those of the parent cooperative- have not produced substantial results in the form of increased worker participation. The cross-national transfer of policies and practices to foreign subsidiaries could be hampered by 'institutional distance', that is, the nature of differences between the regulatory, normative and cognitive institutions of the MNC's country of origin and the subsidiary's country of operation (Ferner et al., 2005), which could hinder the implementation of policies that foster worker participation in the ownership, management and profits at foreign subsidiaries. Furthermore, there is also evidence supporting the assertion that MNCs from more coordinated market economies do not always transfer the more regulated human resources/industrial relations policies and practices to their subsidiaries (e.g. Ferner et al., 2001).

Although these elements and the aforementioned barriers play a role, they do not seem to be the major challenge involving regeneration. The existence of internal obstacles at cooperatives, in the form of reluctance on the part of the members and managers to foster participation at foreign subsidiaries, seems to be more critical.

Mondragon has applied Anglo-Saxon management techniques characterised by a centralised control over the subsidiaries (Ferner et al., 2004) and by a tendency to transfer human resource policies and practices in a standardised and formalised manner (Almond et al., 2005). Mondragon only transfers such practices as quality circles and other forms of small group problem solving, which stand out as management-driven forms of involvement signed to serve goals of improved productivity and flexibility (Boxall et al., 2007). The mini-companies system has been implemented by means of expatriates in the Chinese or Brazilian subsidiaries in order to enhance their economic and organisational performance (Errasti, 2015). Furthermore, probably due to the lesser institutional distance (Muller-Camen et al., 2001) this latter subsidiary has implemented certain aspects of the parent-cooperative's management model such as social equity policies (Luzarraga, 2008: 347). Nonetheless, there is no worker participation in ownership, governing bodies and profits. This exemplifies the necessity of applying an integrated approach to worker participation, since narrow, one-dimensional employee participation initiatives provide poorer levels of organisational performance (Dundon and Gollan, 2007). Such lack of participation is even starker at Fagor Ederlan Slovensko and especially at Fagor Ederlan Auto-Parts Kunshan: at Kunshan, workers do not even have trade union representatives, and their social and labour-related conditions are similar to those of conventional multinationals in the same area (Errasti, 2015).

The main factor behind this lacklustre record seems to be unwillingness to foster autonomy at foreign subsidiaries, because the resulting loss of control over them could jeopardise the jobs of cooperative members at parent companies. Control over the subsidiaries resides to a great extent in the dependency of these on the parent company (Ferner et al., 2005). As is known, the main objective of the internationalisation in Mondragon is to keep the jobs of cooperative members in the Basque plants (Luzarraga and Irizar, 2012). To this end, Mondragon's parent cooperatives retain a hierarchical decision-making power and a hold on strategic elements such as technically advanced production processes, research and development (R\&D) and investment capacity, high valueadded activities and products and so on. (Errasti, 2015; Errasti et al., 2003). If foreign subsidiaries are converted into cooperatives, or even if their workers are given greater autonomy and participation, the control exercised by parent cooperatives may be called into question: workers at subsidiaries could demand a more even distribution of resources and strategic activities, more uniform social and working conditions and so on. In short, uncertainty stemming from the internationalisation could arise among worker members, who might see their jobs as being endangered (Clamp, 2000), because the geographical, social and cultural distances that separate them from the workers 
at foreign subsidiaries (Errasti, 2015) prevent there from being any real feeling of commitment to the cooperative (Altuna, 2008). One of the worker members interviewed put it like this:

It would be very hard to guarantee that workers at Chinese or Slovakian subsidiaries will develop a commitment as strong as ours [as worker members] with a foreign company [Fagor Ederlan], based on a cooperative business model far removed from their own corporate and labour-related culture [...]. If they become members of the cooperative and their business projects then fail, that could seriously compromise our own jobs. (I11, worker member of Fagor Ederlan S. Coop.)

\section{Similarly, the Chair of Fagor Ederlan Tafalla noted,}

The relationship between members of Fagor Ederlan [the parent company] and our workers has been very close since the idea of the cooperativisation was put on the table [...]. There were several visits and meetings between our employees and the parent company members to know and implement its management model [...]. The relationship between Chinese workers and our members is non-existent [...]. Their work culture is very far from the cooperative standards we have in this region [...]. Then, how are we going to make sure that if tomorrow they become members their project will succeed? If it goes wrong, it could destabilize the whole entrepreneurial group and our jobs could be at risk. (I4, Chair of Fagor Ederlan Tafalla)

This is also consistent with research recently conducted by Heras (2014), who concludes that there is a clear decoupling between Mondragon's principles and the daily activity of the worker members, and that the strongest tie binding them to the organisations is not their closeness to the cooperative model and culture, but rather job security. Ultimately, if the members of the Basque plants are not themselves strongly bound to the cooperative principles and values of Mondragon, it seems unlikely that strong interest in extending the cooperative model to foreign subsidiaries will arise.

\section{Discussion and conclusion}

Globalisation and economic pressures have instilled in organisations a rhetoric focused on efficiency and competitiveness that manifests itself in shallow forms of participation at the workplace oriented to improve market performance (Poole et al., 2000). This is evident in Mondragon (Taylor, 1994) and other large employee-owned organisations (Cathcart, 2013), where as Heras (2013) argues, 'pressures for managerialism from both inside and outside, including an omnipresent managerial discourse and rhetoric, have affected internal commitment to core cooperative values' (p. 4).

Our study shows that internationalisation exacerbates degenerative tensions: global market competition engages cooperatives in a trend towards establishing capitalist subsidiaries and hiring non-member workers (Errasti, 2015), while accumulating the decision-making power in the technostructure of parent cooperatives (Errasti et al., 2003). Such developments encourage a weak worker participation culture articulated in mainstream management programmes (Cheney, 1999) and developing a professional management more committed to economic efficiency (Cheney, 2005) in order to meet the complex demands of the international business arena. This scenario, in the terms of Cornforth et al. (1988), entails: a constitutional degeneration, as cooperatives formally adopt capitalist formulas and, following Ben-ner (1984), replace worker-members with a non-member workforce; a goal degeneration, since cooperatives focus on profit-seeking or conventional business goals and an organisational degeneration, as cooperatives come to be controlled by a managerial elite and, following Cornforth (1995), participation and influence of worker-members is diminished. 
The evidence gathered from our analysis, although it illustrates the complexity involved in managing such degenerative tendencies, challenges the determinism of the 'degeneration thesis' and, in line with previous research (Rosner, 1984), supports the contention that the life-cycle of cooperatives does not conclude with degeneration, but may be followed by processes of cooperative regeneration which, as Batstone (1983) stresses, 'breathe life back into cooperative ideals' (p. 150). However, the main contribution of the research resides in analysing the new challenges and opportunities that worker-owned organisations face if they are to regenerate in the current globalised scenario, thus going beyond the recent debates considered in the organisational literature on alternative forms, which have mainly focused in degenerative tendencies and paradoxical practices (e.g. Heras, 2014; Stohl and Cheney, 2001). As the article shows, multinational cooperatives may conduct regeneration schemes by directly converting capitalist subsidiaries into cooperatives and by fostering worker participation in the management, ownership and profits of their enterprises. Unlike previous studies (e.g. Flecha and Ngai, 2014; Storey et al., 2014), we have examined the workings of regeneration in multinational cooperatives in detail, uncovering structural problems.

The success of converting subsidiaries into cooperatives may be limited, first, by the fact that the cooperativisation project was outlined and implemented by the managerial technostructure of the parent company with no involvement of the subsidiary's own workers until the later stages of change, which, as organisational behaviour-based research on worker participation notes (e.g. Gollan, 2007), may be detrimental to the stability and success of organisational change processes. This may also imply conflicts between worker-members and salaried workers, and the exclusion of the latter in the organisational participatory mechanisms after cooperativisation. Furthermore, the debilitation of trade unions is evident in these processes, which may be part of a systematic management strategy oriented towards gaining flexibility and preserving managerial power (Boxall and Purcell, 2010). Moreover, the lack of worker involvement may be reflected in the failure to bind new members to the cooperative principles and values. As the case of Fagor Ederlan suggests, in a context in which individualisation and employment precariousness is prominent, job security is the most important tie binding new members to their cooperatives. This also seems to be part of the aforementioned broader process by which dominant regimes of managerialism have influenced the reshaping of cooperative values such as self-management and participation (Cheney, 2005; Heras, 2014). The prevalence of job security over cooperative identity among worker-members may legitimise the implementation of shallow, managerially oriented forms of participation and, ultimately, pose a perennial challenge for the stability of cooperatives framed within a progressive degeneration.

In addition, our research shows that multinational cooperatives behave in a different way abroad. It underlines that the barriers (economic, legal, cultural and investment-related) identified by previous research (Flecha and Ngai, 2014; Luzarraga, 2008) preventing the cooperativisation of foreign subsidiaries may be, in the terms of Heras (2013), part of the managerial lingua franca spoken by Mondragon and other alternative organisations embedded in global competition. Although our study demonstrates that the cooperativisation of foreign subsidiaries is further complicated by their own national, local and organisational-cultural contexts (Cheney et al., 2014), it suggests above all that the discourse regarding encouraging worker participation in ownership, management and profits at foreign subsidiaries is clearly detached from actions and intentions (Henderson et al., 2007), since cooperatives do not in fact develop solid strategies for cooperativisation and only provide vague indicators and general guidelines for the comparison between parent cooperatives and subsidiaries.

The reality behind this smokescreen seems to be the inner reluctance of parent cooperatives to cooperativise or even foster autonomy at foreign subsidiaries. Recent literature (e.g. Luzarraga and 
Irizar, 2012) suggests that cooperatives usually internationalise as a defensive strategy to safeguard the jobs of cooperative members at local plants. Our investigation demonstrates that this strategy impels multinational cooperatives to adopt a managerialist approach over their foreign subsidiaries: parent cooperatives are reticent to encourage real self-management and merely transfer shallow, managerially oriented forms of participation that mainly aim to enhance the subsidiary's economic and organisational performance and achieve the required flexibility to compete in international markets. The key point underlying the lack of willingness to foster regeneration initiatives at foreign subsidiaries may stem from the 'psychic distance' (Child et al., 2002) — which includes cultural, institutional and spatial factors - between members at parent cooperatives and workers at foreign subsidiaries that would cause the cooperative members' suspicion that the foreign workers may not develop a solid commitment to the cooperative model and to the company.

The achievements and deficiencies of the cooperativisation of Fagor Ederlan Tafalla provide insightful lessons both for the regeneration of multinational cooperatives and for the long-term stability of new and growing cooperatives. First, genuine information, training and education in cooperative values for workers seem to form the most essential components for the stability of cooperatives. These would allow new and growing cooperatives to achieve a sustainable growth on the basis of foundational values and would facilitate large traditional cooperatives retaining their long-held values in a globalised context in which the transmission of cooperative values to new generations is failing (Arnáez-Arce, 2015). We could also expect that a more solid identification with cooperative values at parent cooperatives might trigger a stronger commitment to expanding the cooperative model to foreign subsidiaries. A closer relationship between members at parent cooperatives and foreign workers may encourage a stronger trust, which also seems fundamental for the cooperativisation of subsidiaries. On the part of capitalist subsidiaries, such education and training may develop an organisational culture in workers that establishes a fertile soil for future cooperativisation schemes. According to Cheney et al. (2014), cooperativisation of subsidiaries should recognise not only national and cultural differences but also the preferences of the employees themselves. Therefore, a more detailed picture of the views of workers at foreign plants concerning the cooperative model itself could have enriched this research. In a broader sense, future research could explore the rich 'stakeholder theory' integrating the involvement of different parties affected by organisational impact (Freeman, 2010), not only to harmonise the regeneration of multinational cooperatives, but also to assess the role of such cooperatives in the larger environments where they are rooted, as well as the kind of economic and social development they are promoting in the current globalised setting.

\section{Acknowledgements}

The authors acknowledge the constructive comments of the Editor of Organization and of the three anonymous reviewers, which have helped to improve the article significantly. The authors also wish to thank Vilja Hulden, Clare Abraham and Carmen Marcuello for their comments on earlier drafts. Finally, the authors would like to express gratitude to all interviewees for giving their help and time to this research.

\section{Funding}

The author(s) received no financial support for the research, authorship, and/or publication of this article.

\section{Notes}

1. Two further production plants are shortly to be added (bringing the total to 18) as a result of joint ventures in China with the Infun Group and in Mexico with Grupo Industrial Saltillo.

2. Under the Basque Cooperatives Act, mixed cooperatives are those which have minority shareholders, whose voting rights at the general assembly may be determined exclusively or preferentially on the basis of their capital contributions. 
3. These are members who maintain a corporate link with the cooperative but actually work at an organisation that the cooperative partly owns or works with.

4. The quotes from interviews presented in this article include a code (I(number)) identifying the interviewee, whose job and position are also indicated.

5. For the initial acquisition of $12 \%$ of the capital of the subsidiary in 2008 , each worker member was required to pay $€ 13,000$.

\section{References}

Almond, P., Edwards, T., Colling, T., et al. (2005) 'Unraveling Home and Host Country Effects: An Investigation of the HR Policies of an American Multinational in Four European Countries', Industrial Relations 44(2): 276-306.

Altuna, L. (ed.) (2008) La Experiencia Cooperativa de Mondragón. Una síntesis general. Eskoriatza: Lanki.

Arando, S., Freundlich, F., Gago, M., et al. (2010) 'Assessing Mondragon: Stability \& Managed Change in the Face of Globalization', William Davidson Institute, Working Paper 1003, November. Ann Arbor, MI: University of Michigan. Retrieved July 3, 2014, from http://papers.ssrn.com/sol3/papers.cfm?abstract id $=1726449$

Arnáez-Arce, V. M. (ed.) (2015) Difusión de los valores y principios cooperativos entre la juventud. Madrid: Dykinson.

Arregi, B., Freundlich, F., Lizarraga, N., et al. (2012) Representación y Participación de las Personas en las Empresas. Oñati: Mondragon Knowledge \& Innovation.

Ashforth, B. E. and Reingen, P. H. (2014) 'Functions of Dysfunction Managing the Dynamics of an Organizational Duality in a Natural Food Cooperative', Administrative Science Quarterly 59(3): 474-516.

Azkarraga, J., Cheney, G. and Udaondo, A. (2012) 'Workers Participation in a Globalized Market: Reflections on and from Mondragon', in M. Atzeni (ed.) Alternative Work Organisations, pp. 76-102. New York: Palgrave Macmillan.

Bakaikoa, B., Errasti, A. and Begiristain, A. (2004) 'Governance of the Mondragon Corporación Cooperativa', Annals of Public and Cooperative Economics 75: 61-87.

Bakaikoa, B., Etxezarreta, E. and Morandeira, J. (2013) 'La Regeneración de las Entidades de Economía Social. Un reto en el País Vasco', REVESCO-Revista de Estudios Cooperativos 112: 151-75.

Batstone, E. (1983) 'Organization and Orientation: A Life Cycle Model of French Cooperatives', Economic and Industrial Democracy 4(2): 139-61.

Ben-ner, A. (1984) 'On the Stability of the Cooperative Type of Organization', Journal of Comparative Economics 8(3): 247-60.

Bernstein, P. (1976) Workplace Democratization: Its Internal Dynamics. New Brunswick, NJ: Transaction Books.

Boxall, P. and Purcell, J. (2010) 'An HRM Perspective on Employee Participation', in A. Wilkinson, P. J. Gollan and M. Marchington (eds) The Oxford Handbook of Participation in Organizations, pp. 29-51. Oxford: Oxford University Press.

Boxall, P., Haynes, P. and Macky, K. (2007) 'Employee Voice and Voicelessness in New Zealand', in R. B. Freeman, P. Boxall and P. Haynes (eds) What Workers Say: Employee Voice in the Anglo American Workplace, pp. 125-45. Ithaca, NY: Cornell University Press.

Budd, J. (2004) Employment with a Human Face: Balancing Efficiency, Equity and Voice. Ithaca, NY: Cornell University Press.

Burdin, G. (2014) ‘Are Worker-Managed Firms More Likely to Fail Than Conventional Enterprises? Evidence from Uruguay', Industrial \& Labor Relations Review 67(1): 202-38.

Cathcart, A. (2013) 'Paradoxes of Participation: Non-Union Workplace Partnership in John Lewis', International Journal of Human Resource Management 25(6): 762-80.

Cheney, G. (1999) Values at Work: Employee Participation Meets Market Pressure at Mondragon. Ithaca, NY: Cornell University Press.

Cheney, G. (2005) 'Democracy at Work within the Market: Reconsidering the Potential', in V. Smith (ed.) Worker Participation: Current Research and Future Trends, pp. 179-203. Amsterdam: Emerald Group Publishing Limited. 
Cheney, G., Cruz, I., Peredo, A. M., et al. (2014) 'Worker Cooperatives as an Organizational Alternative: Challenges, Achievements and Promise in Business Governance and Ownership', Organization 21(5): 591-603.

Cheney, G., Straub, J., Speirs, L., et al. (2012) 'Democracy, Participation, and Communication at Work: A Multi-Disciplinary Review', in M. Roloff (ed.) Communication Yearbook 21, pp. 35-91. New York: Routledge.

Chetty, S. (1996) 'The Case Study Method for Research in Small- and Medium-Sized Firms', International Small Business Journal 15(1): 73-85.

Child, J., Ng, S. H. and Wong, C. (2002) 'Psychic Distance and Internationalisation: Evidence from Hong Kong Firms', International Studies of Management \& Organization 32(1): 36-56.

Clamp, C. (2000) 'The Internationalization of Mondragon', Annals of Public and Cooperative Economics 71(4): 557-77.

Cornforth, C. (1995) 'Patterns of Cooperative Management: Beyond the Degeneration Thesis', Economic and Industrial Democracy 16(4): 487-523.

Cornforth, C., Thomas, A., Lewis, R., et al. (1988) Developing Successful Working Co-Operatives. London: Sage.

Côté, D. (ed.) (2001) Holdings Coopératifs: Evolution ou Transformation définitive? Brussels: De Boeck.

Dundon, T. and Gollan, P. J. (2007) 'Re-Conceptualizing Voice in the Non-Union Workplace', International Journal of Human Resource Management 18(7): 1182-98.

Eisenhardt, K. M. (1989) 'Building Theories from Case Study Research', Academy of Management Review 14(4): 532-50.

Elortza, E., Alzola, I. and López, U. (2012) ‘La Gestión de la Crisis en la Corporación Mondragón’, Ekonomiaz 79(1): 58-81.

Errasti, A. (2015) 'Mondragon's Chinese Subsidiaries: Coopitalist Multinationals in Practice', Economic and Industrial Democracy 36(3): 479-99.

Errasti, A., Heras, I., Bakaikoa, B., et al. (2003) 'The Internationalisation of Cooperatives: The Case of the Mondragon Cooperative Corporation', Annals of Public and Cooperative Economics 74(4): 553-84.

Fagor Ederlan (2006) Proyecto de Cooperativización de Fagor Ederlan Tafalla. Eskoriatza: Fagor Ederlan.

Fagor Ederlan (2009) Sustainability Report: 2008. Eskoriatza: Fagor Ederlan.

Fagor Ederlan (2010) Resultados del proyecto de cooperativización de Fagor Ederlan Tafalla: Participación y compromiso de los trabajadores. Tafalla: Fagor Ederlan.

Fagor Ederlan (2015) Sustainability Report: 2014. Eskoriatza: Fagor Ederlan.

Ferner, A., Almond, P. and Colling, T. (2005) 'Institutional Theory and the Cross-National Transfer of Employment Policy: The Case of 'Workforce Diversity' in US Multinationals', Journal of International Business Studies 36(3): 304-21.

Ferner, A., Almond, P., Clark, I., et al. (2004) 'The Dynamics of Central Control and Subsidiary Autonomy in the Management of Human Resources: Case-Study Evidence from US MNCs in the UK', Organization Studies 25(3): 363-91.

Ferner, A., Quintanilla, J. and Varul, M. (2001) 'Country-of-Origin Effects, Host-Country Effects, and the Management of HR in Multinationals: German Companies in Britain and Spain', Journal of World Business 36(2): 107-27.

Flecha, R. and Ngai, P. (2014) 'The Challenge for Mondragon: Searching for the Cooperative Values in Times of Internationalization', Organization 21(5): 666-82.

Forcadell, F. J. (2005) 'Democracy, Cooperation and Business Success: The Case of Mondragón Corporación Cooperativa', Journal of Business Ethics 56(3): 255-74.

Freeman, R. E. (2010) Strategic Management: A Stakeholder Approach. New York: Cambridge University Press.

Gollan, P. J. (2007) Employee Representation in Non Union Firms. London: Sage.

Henderson, A., Weaver, C. K. and Cheney, G. (2007) 'Talking 'Facts': Identity and Rationality in Industry Perspectives on Genetic Modification', Discourse Studies 9(1): 9-41.

Heras, I. (2013) 'Do Co-Ops Speak the Managerial Lingua Franca? An Analysis of the Managerial Discourse of Mondragon Cooperatives', SSRN Working Paper. Retrieved February 7, 2016, from www.researchgate.net/publication/256047223 
Heras, I. (2014) 'The Ties That Bind? Exploring the Basic Principles of Worker-Owned Organizations in Practice', Organization 21(5): 645-65.

Irizar, I. (2005) Empresa Cooperativa y Liderazgo. Oñati: Mondragon Unibertsitatea.

Koop (2015) 'Fagor Ederlan Taldea S.Coop', Koop 63: 6-7.

Lanki (2007) Viabilidad del proyecto de transformación de Fagor Ederlan Brasileira. Eskoriatza: Lanki.

Luzarraga, J. M. (2008) ‘Mondragon Multi-Localisation Strategy: Innovating a Human Centred Globalisation', PhD Thesis, Mondragon Unibertsitatea.

Luzarraga, J. M. and Irizar, I. (2012) 'La Estrategia de Multilocalización Internacional de la Corporación Mondragón', Ekonomiaz 79: 114-45.

Luzarraga, J. M., Aranzadi, D. and Irizar, I. (2007) 'Understanding Mondragon Globalization Process: Local Job Creation through Multi-Localization', 1st CIRIEC International Research Conference on the Social Economy, Victoria, BC, Canada, 22-25 October.

McMurtry, J. and Reed, D. (2009) Co-Operatives in a Global Economy: The Challenges of Co-Operation across Borders. Newcastle: Cambridge Scholars Publishing.

Meister, A. (1974) La participation dans les associations. Paris: Editions Ouvrières.

Meister, A. (1984) Participation, Associations, Development and Change. New Brunswick, NJ: Transaction Books.

Miyazaki, H. (1984) 'On Success and Dissolution of the Labour-Managed Firm in the Capitalist Economy', Journal of Political Economy 92(5): 909-31.

Mondragon (2006) 'Fagor Ederlan impulsa el proceso de cooperativización de FIT Automoción'. Retrieved 10 June, 2014, from www.mondragon-corporation.com/fagor-ederlan-impulsa-el-proceso-de-cooperativizacion-de-fit-automocion

Mondragon (2013) Corporate Management Model. Mondragón: Mondragon Corporation.

Mondragon (2015) 2014 Annual Report. Mondragón: Mondragon Corporation.

Morrison, E. W. and Milliken, F. J. (2000) 'Organizational Silence: A Barrier to Change and Development in a Pluralistic World', Academy of Management Review 25(4): 706-25.

Muller-Camen, M., Almond, P., Gunnigle, P., et al. (2001) 'Between Home and Host Country: Multinationals and Employment Relations in Europe', Industrial Relations Journal 32(5): 435-48.

Myers, M. D. (2009) Qualitative Research in Business and Management. London: Sage.

Paranque, B. and Willmott, H. (2014) 'Cooperatives-Saviours or Gravediggers of Capitalism? Critical Performativity and the John Lewis Partnership', Organization 21(5): 604-25.

Parker, M., Cheney, G., Fournier, V., et al. (eds) (2014) The Routledge Companion to Alternative Organization. London: Routledge.

Poole, M., Lansbury, R. and Wailes, N. (2000) 'A Comparative Analysis of Developments in Industrial Democracy', Industrial Relations 40(3): 490-525.

Rosner, M. (1984) ‘A Search for 'Coping Strategies' or Forecasts of Cooperative Degeneration?', Economic and Industrial Democracy 5(3): 391-9.

Rothschild-Whitt, J. (1976) 'Conditions Facilitating Participatory Democratic Organisation', Sociological Inquiry 46(2): 75-86.

Rothschild-Whitt, J. and Whitt, J. A. (1986) The Co-Operative Workplace: Potentials and Dilemmas of Organizational Democracy and Participation. New York: Cambridge University Press.

Sauser, W. I. (2009) 'Sustaining Employee Owned Companies: Seven Recommendations', Journal of Business Ethics 84(2): 151-64.

Spear, R. (2004) 'Governance in Democratic Member-Based Organisations', Annals of Public and Cooperative Economics 75(1): 33-60.

Stohl, C. and Cheney, G. (2001) 'Participatory Processes/Paradoxical Practices', Management Communication Quarterly 14(3): 349-407.

Storey, J., Basterretxea, I. and Salaman, G. (2014) 'Managing and Resisting 'Degeneration' in EmployeeOwned Businesses: A Comparative Study of Two Large Retailers in Spain and the United Kingdom', Organization 21(5): 626-44.

Stryjan, Y. (1994) 'Understanding Cooperatives: The Reproduction Perspective', Annals of Public and Cooperative Economics 65(1): 59-80. 
Taylor, P. L. (1994) 'The Rhetorical Construction of Efficiency: Restructuring and Industrial Democracy in Mondragon, Spain', Sociological Forum 9(3): 459-89.

TuLankide (2004) 'Empresa personalista, una opción más justa', TuLankide 493: 3-4.

Ugalde, A., Arrizubieta, J. and Elcano, C. (2009) Cooperativización de Actividades y Empresas: Aspectos procedimentales y motivacionales. Mondragón: Mondragón Unibertsitatea.

Varman, R. and Chakrabarti, M. (2004) 'Contradictions of Democracy in a Workers' Cooperative', Organization Studies 25(2): 183-208.

Webb, S. and Webb, B. (1920) A Constitution for the Socialist Commonwealth of Great Britain. London: Longmans.

Wilkinson, A., Gollan, P., Marchington, M., et al. (2010) 'Conceptualising Employee Participation in Organisations', in A. Wilkinson, P. J. Gollan and M. Marchington (eds) The Oxford Handbook of Participation in Organizations, pp. 1-25. Oxford: Oxford University Press.

Wood, G. (2010) 'Employee Participation in Developing and Emerging Countries', in A. Wilkinson, P. J. Gollan and M. Marchington (eds) The Oxford Handbook of Participation in Organizations, pp. 552-69. Oxford: Oxford University Press.

Yin, R. K. (2003) Case Study Research: Design and Methods, 3rd ed. London: Sage.

\section{Author biographies}

Ignacio Bretos is a young scholar currently conducting his doctoral studies in Economics and Management at the University of Zaragoza (Spain). He is also a researcher at the GEZKI-Institute of Cooperative Law and Social Economy of the University of the Basque Country in San Sebastian (Spain). His main research deals with the social and economic impact of social economy organisations, the organisational behaviour of cooperatives and the internationalisation of alternative organisations such as cooperatives and non-profit organisations.

Anjel Errasti is a Senior Lecturer in Strategic Management at the Faculty of Economics and Business of the University of the Basque Country in San Sebastian (Spain), where he is also a researcher at the GEZKI-Institute of Cooperative Law and Social Economy. His research interests focus on cooperatives and social economy, public policies, employment, Mondragon cooperatives, multinational corporations and globalisation. 